\title{
IMPLEMENTASI PEMBELAJARAN TEMATIK DALAM PENDEKATAN SAINTIFIK PADA MATA PELAJARAN FIQIH KELAS VI DI MIN 1 KOTA BIMA
}

\author{
Syahru Ramadhan dan Muslim \\ Institut Agama Islam (IAI) Muhammadiyah Bima \\ Email: syahrupgmi05@gmail.com \\ muslimanjas@gmail.com
}

\begin{abstract}
Abstrak
MIN 1 Kota Bima merupakan sekolah dasar (madrasah) berbasis Islam yang menerapkan pembelajaran berdasarkan kurikulum 2013. Proses pembelajaran menggunakan paradigma baru yaitu pembelajaran tematik dengan menggunakan pendekatan saintifik. Paradigma baru ini mengarahkan peserta didik untuk memposisikan diri sebagai subyek pembelajaran, sehingga siswa dapat terlibat secara aktif dalam kegiatan pembelajaran. Mata pelajaran fiqih selama ini diajarkan dengan cara menuntut siswa menghafal, sehingga hal ini sudah tidak kontektual lagi zamannya. Pola ini juga membuat kesan bahwa guru memposisikan siswa sebagai obyek pembelajaran yang harus selalu diisi. Penelitian ini menggunakan pendekatan kualitatif dengan jenis penelitian studi kasus. Metode pengumpulan data dengan wawancara, observasi, dan dokumentasi. Adapun sumber informan dalam penelitian ini adalah kepala sekolah, Wakasek Kurikulum dan guru mata pelajaran fiqih. Sedangkan metode analisis data menggunakan teknik analisis deskriptif. Hasil temuan dalam penelitian ini adalah Pembelajaran tematik dengan menggunakan pendekatan saintifik untuk mata pelajaran fiqih siswa kelas VI di MIN 1 Kota Bima menggunakan pendekatan pembelajaran yang berpusat kepada siswa, menekankan pada proses pembelajaran yang berangkat dari dalam diri siswa sendiri. Maksudnya bahwa yang mengkonstruksi pengetahuan adalah siswa sendiri, bukan guru yang mentransfer pengetahuan kepada siswa. Guru disini hanya bertugas sebagai fasilitator dan dinamisator. Kegiatan pembelajarannya menuntut siswa aktif sehingga dapat menciptakan proses pembelajaran bermakna.
\end{abstract}

Kata Kunci : Pembelajaran Tematik, Saintifik, Fiqih

\section{PENDAHULUAN}

I

mplementasi Kurikulum 2013 di sekolah/madrasah yang sudah dimulai di sejumlah sekolah dasar merupakan salah satu bentuk inovasi pendidikan yang dilakukan oleh pemerintah (Andi Prastowo, 2015). Dalam pandangan Ridwan Abdullah Sani, pengembangan Kurikulum 2013 ini merupakan upaya peningkatan mutu pendidikan untuk menghasilkan lulusan yang kreatif dan mampu 
menghadapi kehidupan di masa yang akan dating (Ridwan Abdul Sani, 2013).

Pembelajaran tematik merupakan salah satu model pembelajaran terpadu (integrated intruction) yang merupakan suatu sistem pembelajaran yang memungkinkan siswa, baik secara individu maupun kelompok aktif menggali dan menemukan konsep serta prinsip-prinsip keilmuan secara holistik, bermakna, dan otentik (Abdul Majid, 2014). Menurut Kamus Besar Bahasa Indonesia edisi terbaru, "tematik" diartikan sebagai "berkenaan dengan tema", dan "tema" sendiri berarti "pokok pikiran, dasar cerita (yang dipercakapkan, dipakai sebagai dasar mengarang, mengubah sajak, dan sebagainya)" (Andi Prastowo, 2013). Dalam pembelajaran tematik, proses pembelajarannya menggunakan pendekatan scientific. Hal ini dimaksudkan untuk memberikan pemahaman kepada peserta didik dalam mengenal, memahami berbagai materi menggunakan pendekatan ilmiah, bahwa informasi bisa berasal dari mana saja, kapan saja, tidak bergantung pada informasi searah dari guru (Abdul Majid, 2014).

Pembelajaran berbasis pendekatan ilmiah itu lebih efektif hasilnya dibandingkan dengan pembelajaran tradisional, retensi informasi dari guru sebesar 10 persen setelah 15 menit dan perolehan pemahaman kontekstual sebesar 25 persen. Pada pembelajaran berbasis pendekatan ilmiah, retensi informasi dari guru sebesar lebih dari 90 persen setelah dua hari dan perolehan pemahaman kontekstual sebesar 50-70 persen (Daryanto, 2014).

Pendekatan saintifik merupakan pendekatan pembelajaran yang berorientasi atau berpusat pada siswa (student centered approach). Pendekatan saintifik merupakan proses pembelajaran yang dirancang sedemikian rupa agar peserta didik secara aktif mengkonstruksi konsep, hukum, atau prinsip melalui tahapan-tahapan mengamati (untuk mengidentifikasi atau menemukan masalah), merumuskan masalah, mengajukan atau merumuskan hipotesis, mengumpulkan data dengan berbagai teknik, menganalisis data, menarik kesimpulan dan mengkomunikasikan konsep, hukum atau prinsip yang ditemukan (Daryanto, 2014). 
MIN 1 Kota Bima merupakan sekolah dasar (madrasah) berbasis Islam yang menerapkan pembelajaran berdasarkan kurikulum 2013. Proses pembelajaran menggunakan paradigma baru yaitu pembelajaran tematik dengan menggunakan pendekatan saintifik. Paradigma baru ini mengarahkan peserta didik untuk memposisikan diri sebagai subyek pembelajaran, sehingga siswa dapat terlibat secara aktif dalam kegiatan pembelajaran. Mata pelajaran fiqih selama ini diajarkan dengan cara menuntut siswa menghafal, sehingga hal ini sudah tidak kontektual lagi zamannya. Pola ini juga membuat kesan bahwa guru memposisikan siswa sebagai obyek pembelajaran yang harus selalu diisi. Oleh karena itu, pembelajaran tematik dengan pendekatan saintifik diharapkan dapat memberikan dampak positif bagi peserta didik khususnya dalam mata pelajaran fiqih. Jika dilihat dari realitas kehidupan umat islam pada saat ini, ketika ditanyakan terkait dengan persoalan-persoalan yang berkaitan dengan ajaran islam banyak tidak tahu. Hal ini disebabkan karena tingkat pengetahuannya yang sangat minim. Selain itu, kurangnya kesadaran umat islam untuk mempelajari ajaran islam secara tersebut.

Berangkat dari beberapa persoalan yang telah jelaskan oleh penulis diatas maka implementasi pembelajaran tematik dalam pendekatan saintifik pada mata pelajaran fiqih di MIN 1 Kota Bima sangat penting untuk diteliti dan dikaji secara ilmiah, agar kedepan dapat diformulasikan sebuah desain pembelajaran mata pelajaran fiqih di MI yang sesuai dengan kurikulum 2013.

\section{TINJAUAN TEORITIS}

\section{Pembelajaran Tematik}

Pembelajaran tematik merupakan salah satu model pembelajaran terpadu (integrated instruction) yang merupakan suatu system pembelajaran yang memungkinkan siswa, baik secara individu maupun kelompok aktif menggali dan menemukan konsep serta prinsip-prinsip keilmuan secara holistik, bermakna dan otentik (Abdul Majid, 2014). Dalam pembelajaran efektif dan bermakna, peserta didik perlu dilibatkan secara aktif, karena mereka adalah pusat dari kegiatan pembelajaran serta pembentukan kompetensi dan karakter (Mulyasa, 2013). 
Pembelajaran tematik lebih menekankan pada keterlibatan siswa dalam proses pembelajaran, sehingga siswa dapat memperoleh pengalaman langsung dan terlatih untuk dapat menemukan sendiri berbagai pengetahuan yang dipelajarinya. Melalui pengalaman langsung, siswa akan memahami konsep-konsep yang mereka pelajari dan menghubungkannya dengan konsep lain yangtelah dipahaminya.karena itu, pembelajaran tematik lebih menekankan pada penerapan konsep belajar sambil melakukan sesuatu. Guru perlu mengemas atau merancang pengalaman belajar yang akan mempengaruhi kebermaknaan belajar siswa. Pengalaman belajar yang menunjukan kaitan unsur-unsur konseptual menjadikan proses pembelajaran lebih efektif. Kaitan konseptual antar mata pelajaran yang dipelajari akan membentuk skema, sehingga siswa akan memperoleh keutuhan dan kebulatan pengetahuan. Selain itu, dengan penerapan pembelajaran tematik di sekolah dasar akan sangat membantu siswa, karena sesuai dengan tahap perkembangannya, siswa masih melihat segala sesuatu sebagai satu keutuhan (M. Hosnan, 2014).

Sementara itu, pembelajaran tematik memiliki karakteristik sebagai berikut: (1) Berpusapada siswa (student centered). Hal ini sesuai dengan pendekatan belajar modern yang lebih banyak menempatkan siswa sebagai subjek belajar, sedangkan guru lebih banyak berperan sebagai fasilitator. (2) Memberikan pengalaman langsung. Pembelajaran tematik dapat memberikan pengalaman langsung kepada siswa. Dengan pengalaman langsung ini, siswa dihadapkan pada sesuatu yang nyata (konkret) sebagai dasar untuk memahami hal-hal yang lebih abstrak. (3) Pemisahan mata pelajaran tidak begitu jelas. Dalam pembelajaran tematik, pemisahan antar mata pelajaran menjadi tidak begitu jelas. Fokus pembelajaran diarahkan kepada pembahasan tema-tema yang paling dekat berkaitan dengan kehidupan siswa. (4) Menyajikan konsep dari berbagai mata pelajaran. Pembelajaran tematik menyajikan konsepkonsep dari berbagai mata pelajaran dalam suatu proses pembelajaran. Dengan demikian, siswa mampu memahami konsep-konsep tersebut secara utuh (Hartono, 2011). 


\section{Pendekatan Saintifik}

Dalam kurikulum 2013, proses pembelajaran di sekolah/madrasah menggunakan pendekatan saintifik. Hal ini dimaksudkan untuk memberikan pemahaman kepada siswa dalam mengenal dan memahami berbagai materi menggunakan pendekatan ilmiah. Maksudnya informasi bisa berasal dari mana saja, kapan saja, tidak bergantung pada informasi searah dari guru. Oleh karena itu kondisi pembelajaran yang diharapkan tercipta diarahkan untuk mendorong siswa dalam mencari tahu dan berbagai sumber observasi bukan diberi tahu (Abdul Majid, 2014).

Lebih lanjut diungkapkan pula bahwa guru dituntut harus memberikan kemudahan untuk proses ini, dengan mengembangkan suasana belajar yang memberi kesempatan siswa untuk menemukan, menerapkan ide-ide mereka sendiri, menjadi sadar dan secara sadar menggunakan strategi mereka sendiri untuk belajar. Guru mengembangkan kesempatan belajar kepada siswa untuk meniti anak tangga yang membawa mereka kepemahaman yang lebih tinggi, yang semula dilakukan dengan bantuan guru tetapi semakin lama semakin mandiri. Oleh karena itu, bagi siswa, pembelajaran harus bergeser dari "diberi tahu menjadi "aktif mencari tahu” (Permendikbud RI, 2013).

Implementasi Kurikulum 2013 dalam pembelajaran dengan pendekatan saintifik adalah proses pembelajaran yang dirancang sedemikian rupa agar peserta didik secara aktif mengkonstruk konsep, hukum atau prinsip melalui tahapan-tahapan mengamati (untuk mengidentifikasi atau menemukan masalah), merumuskan masalah, mengajukan atau merumuskan hipotesis, mengumpulkan data dengan berbagai tekhnik, menganalisis data, menarik kesimpulan, dan mengkomunikasikan konsep, hukum atau prinsip yang ditemukan. Penerapan pendekatan saintifik dalam pembelajaran melibatkan ketrampilan proses, seperti mengamati, mengklasifikasi, mengukur, meramalkan, menjelaskan, dan menyimpulkan. Proses-proses tersebut bantuan guru sangat diperlukan (M. Hosnan, 2014). 


\section{Mata Pelajaran Fiqih di MI}

Lukman Zain mengungkapkan bahwa kata fiqih secara bahasa adalah al-fahm (pemahaman). Pada awalnya kata fiqih digunakan untuk semua bentuk pemahaman atas Al-Qur'an, Hadits dan bahkan sejarah. Pemahaman atas ayat-ayat dan hadits-hadits teologi, dulu diberi nama fiqih juga. Namun setelah terjadi spesialisasi ilmu-ilmu agama, kata fiqih hanya digunakan untuk pemahaman atas syari'at (agama), itupun hanya berkaitan dengan hukum-hukum perbuatan manusia (Lukman Zain MS, 2009).

Hal yang sama juga disampaikan Suhartini. Ia menjelaskan bahwa fiqih adalah pemahaman yang mendalam dan membutuhkan pengerahan potensi akal. Sebagai dasar penjelasannya adalah isyarat yang muncul dari berbagai ayat Al-Qur'an seperti Qs Thaha ayat 27-28, QS An-Nisa ayat 78, dan QS Hud ayat 91. Sementara itu, beberapa hadits yang memberikan isyarat yang sama dengan kandungan beberapa ayat Al-Qur'an tersebut diataranya yaitu "Apabila Allah menginginkan kebaikan bagi seseorang. Dia akan memberikan pemahamanpemahaman agama (yang mendalam) kepadanya" (Andewi Suhartini, 2012).

Fiqih di Madrasah Ibtidaiyah adalah salah satu mata pelajaran agama Islam yang mengajarkan kepada siswa tentang ibadah mahdhah dan ibadah gairu mahdhah. Menurut Fakrur Rozi, ibadah mahdhah adalah ibadah yang ketentuannya pasti atau istilah lainnya adalah ibadah khassah (ibadah murni atau ibadah khusus) yaitu ibadah yang ketentuan dan pelaksanaannya telah ditetapkan oleh nash dana merupakan sari ibadah kepada Allah seperti: Shalat, zakat, puasa, haji. Ibadah gairu mahdhah adalah sosial, politik, budaya, ekonomi, pendidikan, lingkungan hidup, kemiskinan dan lain sebagainya (Fakrur Rozi, 2004).

\section{METODOLOGI PENELITIAN}

Penelitian ini bertujuan untuk mendiskripsikan secara umum tentang pembelajaran tematik dengan menggunakan pendekatan saintifik pada mata pelajaran fiqih kelas VI di MIN 1 Kota Bima. Penelitian ini menggunakan pendekatan kualitatif dengan jenis penelitian studi kasus. Metode pengumpulan data dengan wawancara, observasi, dan 
dokumentasi (Jhon Creswell, 2014). Adapun sumber informan dalam penelitian ini adalah kepala sekolah, Wakasek Kurikulum dan guru mata pelajaran fiqih. Adapun metode pengumpulan data dalam penelitian adalah melalui observasi, wawancara dan dokumentasi (Suharsimi Arikunto, 2006). Metode analisis data menggunakan teknik analisis deskriptif.

\section{HASIL TEMUAN}

Proses pembelajaran Fiqih dengan pendekatan pembelajaran saintifik terdiri dari lima pengalaman belajar pokok: pertama, mangamati, kedua, menanya, ketiga, mengumpulkan informasi, keempat, mengasosiasi, dan kelima mengasosiasikan. Kelima pengalaman tersebut telah mampu diimplmentasikan dalam kegiatan pembelajaran yang dilaksanakan di MIN 1 Kota Bima pada kelas VI untuk mata pelajaran fiqih sebagaiman yang telah disampaikan oleh Ibu Rahmilah.

"Proses pembelajaran pada mata pelajaran fiqh di MI disesuaikan dengan model pembelajaran yang diterapkan di Kurikulum 2013 yakni dengan menggunakan pendekatan saintifik. Berdasarkan pendekatan ini, maka siswa diarahkan untuk berpikir dan bertindak secara ilmiah. Fiqih sebagai mata pelejaran yang membahas terkait dengan hukum-hukum dalam syariat Islam tidak menjadi terkesan kaku dan menakutkan bagi yang mempelajarinya. Semua dipelajari dan dikaji sesuai dengan fakta dan kemampuan yang dimiliki oleh siswa. Proses mengamati, menanya, mengumpulkan informasi, mengasosiasikan dan mengkomunikasikan kami sebagai guru menganggapnya sebagai sebuah pendekatan pembelajaran yang sangat sesuai dengan kondisi yang sedang kita hadapi sekarang" (Rahmilah, 2019).

Dari penjelasan yang disampaikan oleh responden diatas, maka kegiatan pembelajaran yang dilaksanakan di MIN 1 Kota Bima pada mata pelajaran fiqih sudah benar-benar menggunakan pendekatan pembelajaran saintifik. Pendekatan pembelajaran saintifik adalah suatu pendekatan pembelajaran yang berpusat pada siswa, menekankan pada proses pembelajaran yang berangkat dari dalam diri siswa sendiri. Maksudnya bahwa yang mengkonstruksi pengetahuan adalah siswa sendiri, bukan guru yang mentranfer pengetahuan kepada siswa. Guru disini hanya sebagai fasilitator dan dinamisator. 
1. Perencanaan Pembelajaran Tematik Dengan Pendekatan Saintifik Pada Mata Pelajaran Fiqih Kelas VI di MIN 1 Kota Bima

Sebelum mengetahui lebih lanjut mengenai pembelajaran yang diterapkan di MIN 1 Kota Bima, hendaknya terlebih dahulu mengetahui kurikulum yang diterapkan di madrasah ini. Sesuai dengan apa yang dikatakan bapak Lukman Karim, S.Pd selaku wakasek kurikulum di MIN 1 Kota Bima sebagai berikut:

"Disekolah ini sudah menerapkan kurikulum 2013 setelah pemerintah memberlakukan kurikulum 2013. Namun pada proses pelaksanaannya dilakukan secara bertahap terlebih dahulu. Artinya tidak langsung serta merta dilaksanakan. Para guru mempelajari terlebih dahulu perbedaan dengan kurikulum sebelumnya. Dalam kurikulum 2013 ini pembelajarannya berbasis tematik dan lebih ditekankan untuk bersifat saintifik. Secara formal kurikulum 2013 sudah diterapkan sejak 2015/2016 karena sudah membuat silabus dan RPP. Namun secara proses masih belum maksimal karena berbagai kendala"(Lukman Karim 2019).

Berkenaan dengan pembelajaran fiqih pada kelas VI dengan pendekatan saintifik di sekolah ini, maka guru mata pelajaran fiqih terlebih dahulu melakukan perencanaan. Perencanaan pembelajaran dilakukan oleh guru mata pelajaran fiqih anatara lain silabus mata pelajaran fiqih yang mana pada dasarnya silabus ini sudah ditentukan oleh pemerintah. Oleh karena itu, dalam aplikasinya guru tinggal menjalankan sesuai dengan yang ditentukan oleh pemerintah. Selain silabus, ada juga Rencana Pelaksanaan Pembelajaran (RPP) yang merupakan pengembangan dari silabus. Dalam RPP ini lebih dirinci atau diuraikan yang terdapat dalam silabus. Pada dasarnya RPP ini merupakan perencanaan yang berisi langkah-langkah yang akan dilakukan guru selama proses pembelajaran berlangsung. Hal ini dimaksudkan supaya dalam pembelajarannya nanti akan berjalan dengan baik dan berhasil. Oleh sebaba itu, adanya RPP memberikan arahan kepada guru untuk dapat mengimpelementasikan pembelajaran fiqih dengan baik dan benar dengan menggunakan pendekatan saintifik dalam pembelajaran tematik di MIN 1 Kota Bima.

Penyusunan RPP untuk mata pelajaran fiqih di MIN 1 Kota Bima merujuk pada pedoman umum pembelajaran yang telah 
diterbitkan dalam Permendikbud RI Nomor 81a Tahun 2013 tentang Implementasi Kurikulum. Dalam pedoman ini diungkapkan bahwa Rencana Pelaksanaan Pembelajaran (RPP) adalah rencana pembelajaran yang dikembangkan secara rinci dari suatu materi pokok atau tema tertentu yang mengacu pada silabus. RPP mencakup: pertama, data sekolah, mata pelajaran, dan kelas/semester, kedua, materi pokok, ketiga, alokasi waktu, keempat, tujuan pembelajaran, KD dan indikator pencapaian kompetensi, kelima, materi pembelajaran, metode pembelajaran, keenam, media, alat dan sumber belajar, ketujuh, langkah-langkah kegiatan pembelajaran, dan kedelapan, penilaian.

Dari penjelasan diatas, guru mata pelajaran fiqih di MIN 1 Kota Bima rata-rata telah mampu membuat RPP sebagaiman pedoman yang telah dijelaskan sebelumnya. RPP ini dibuat sebagai acuan dalam mengimplementasikan pembelajaran sesuai dengan tujuan pembelajaran. Lukman Karim menjelaskan, guru di MIN 1 Kota Bima secara rata-rata telah mampu membuat RPP dengan baik dan benar (Lukman Karim, 2019). Hal ini menunjukan bahwa guru di MIN 1 Kota telah mencapai kualifikasi sebagai guru yang professional.

2. Pelaksanaan Pembelajaran Tematik Dengan Pendekatan Saintifik Pada Mata Pelajaran Fiqih di MIN 1 Kota Bima

Dalam proses pelaksanaannya pembelajaran pada mata pelajaran fiqih di MIN 1 Kota Bima Gunawan menyebutkan, bahwa sasaran utama dalam kegiatan pembelajaran adalah: pertama, keterlibatan siswa secara maksimal dalam proses kegiatan pembelajaran, kedua, keterarahan kegiatan secara logis dan sistematis pada tujuan pembelajaran, ketiga, mengembangkan sikap percaya diri pada diri siswa tentang apa yang telah ditemukan dalam proses pembelajaran (Gunawan, 2019). Pembelajaran tematik dengan pendekatan saintifik untuk mata pelajaran fiqih di MIN 1 Kota Bima tidak hanya mengembangkan kemampuan intelektual, tetapi seluruh potensi yang ada, termasuk pengembangan sikap dan keterampilan. 
Berikut penjelasan proses pelaksanaan pembelajaran pada mata pelajaran fiqih di MIN1 Kota Bima dengan menggunakan pendekatan saintifik:

a. Mengajukan Pertanyaan atau Permasalahan

Kegiatan pembelajaran dimulai ketika pertanyaan atau permasalahan diajukan. Untuk meyakinkan bahwa pertanyaan sudah jelas, pertanyaan tersebut dituliskan dipapan tulis, kemudian siswa diminta untuk merumuskan hipotesis. Dalam proses pelaksanaan pembelajaran fiqih kelas VI di MIN Kota Bima guru membimbing siswa untuk mengidentifikasi masalah yang terjadi. Setelah itu guru membagi siswa kedalam beberapa kelomok (Rahmilah, 2019). Pembagian kelompok dilakukan oleh guru supaya siswa terlibat secara aktif dalam kegiatan pembelajaran dan mendiskusikan masalah yang telah ditemukan supaya bisa rumuskan hipotesis.

b. Merumuskan Hipotesis

Hipotesis adalah jawaban sementara atas pertanyaan atau solusi permasalahan yang dapat diuji dengan data. Untuk memudahkan proses ini, maka guru guru mata pelajaran fiqih di MIN 1 Kota Bima menanyakan kepada siswa gagasan mengenai hipotesis yang mungkin dari semua gagasan yang ada, dipilih salah satu hipotesis yang relevan dengan permasalahan yang sudah diberikan sebelumnya. Ibu Sri Andriani dalam kegiatan pembelajaran pada mata pelajaran fiqih untuk materi berwudhu memberikan kesempatan pada siswa untuk curah pendapat dalam membentuk hipotesis (Sri Andriani, 2019). Beliau membimbing siswa dalam menentukan hipotesis yang relevan dengan permasalahan dan memprioritaskan hipotesis mana yang menjadi prioritas penyelidikan.

c. Mengumpulkan Data

Kegiatan pembelajaran mata pelajaran fiqih sebagaimana disebutkan oleh ibu sri andriani mengharuskan siswa untuk mengumpulkan informasi-informasi yang telah didiskusikan sebelumnya. Informasi yang dihasilkan itu berupa data dalam 
bentuk tabel, matrik atau grafik (Sri Andriani, 2019). Setelah itu siswa diberikan kesempatan untuk menentukan langkah-langkah yang sesuai dengan hipotesis yang akan dilakukan. Guru membimbing siswa mengurutkan langkah-langkah percobaan.

d. Analisis Data

Siswa bertanggung jawab menguji hipotesis yang telah dirumuskan dengan menganalisis informasi yang telah diperoleh. Faktor penting dalam menguji hipotesis adalah pemikiran benar atau salah. Setelah memperoleh kesimpulan dari informasi yang didapatkan, siswa dapat menguji hipotesis yang telah dirumuskan. Proses ini dilakukan, agar siswa di MIN 1 Kota Bima khususnya kelas VI terbiasa dengan pembelajaran dengan pendekatan ilmiah. Sebab setiap informasi yang didapatkan harus dikaji, ditelaah dan dianalisis melalui konstruksi keilmuan yang relevan dengan konteks pembelajaran abad 21 yang mengharuskan siswa untuk mengolah pikiran melalui kegiatan pembelajaran.

e. Membuat Kesimpulan

Langkah terakhir dalam kegiatan pembelajaran tematik dengan pendekatan saintifik pada mata pelajaran fiqih kelas VI di MIN 1 Kota Bima adalah membuat kesimpulan. Nurjanah menyebutkan, kami memberikan kesempatan kepada setiap kelompok untuk menyampaikan hasil pengolahan informasi (data) yang terkumpul, setelah itu siswa dibimbing untuk membuat kesimpulan (Nurjanah, 2019).

Dari penjelasan diatas dapat dipahami bahwa pembelajaran tematik dengan menggunakan pendekatan saintifik untuk mata pelajaran fiqih siswa kelas VI di MIN 1 Kota Bima adalah menggunakan pendekatan pembelajaran yang berpusat kepada siswa, menekankan pada proses pembelajaran yang berangkat dari dalam diri siswa sendiri. Maksudnya bahwa yang mengkonstruksi pengetahuan adalah siswa sendiri, bukan guru yang mentransfer pengetahuan kepada siswa. Guru disini hanya bertugas sebagai fasilitator dan dinamisator. Kegiatan pembelajarannya menuntut siswa aktif sehingga dapat menciptakan proses pembelajaran bermakna. Selain 
itu, pembelajaran tematik dengan pendekatan saintifik menekankan pada pembelajaran yang kontekstual sesuai dunia nyata siswa.

3. Evaluasi (Penilaian) Pembelajaran Tematik Dengan Pendekatan Saintifik Pada Mata Pelajaran Fiqih di MIN 1 Kota Bima

Kegiatan penilaian untuk pembelajaran fiqih di MIN 1 Kota Bima pada kurikulum 2013 ini menekankan penggunaan penilaian autentik. Sebagaimana disampaikan oleh bapak Gunawan selaku Kepala Sekolah MIN 1 Kota Bima.

"Salah satu bentuk penekanan yang akan disampaikan kepada guru terkait dengan penilaian siswa di kurikulum 2013 ini adalah penilaian autentik. Sebenarnya pada kurikulum sebelumnya yakni Kurikulum Tingkat Satuan Pendidikan (KTSP) sudah memberi ruang pada penilaian autentik, tetapi dalam implementasi di sekolah khususnya di MIN 1 Kota Bima belum berjalan secara optimal. Melalui penilaian autentik ini Alhamdulillah dengan penekanan yang serius dari guru khususnya guru mata pelajaran fiqih agar benar-benar memperhatikan penilaian autentik, supaya hasil pembelajaran yang telah berlangsung sesuai dengan tujuan pembelajaran yang hendak ingin dicapai oleh guru dan sekolah" (Gunawan, 2019).

Dilihat dari ruang lingkupnya, penilaian pada pembelajaran fiqih di MIN 1 Kota Bima mencakup kompetensi pengetahuan, kompetensi sikap, dan kompetensi keterampilan. Dalam hal ini, bahwa penilaian hasil belajar siswa mencakup kompetensi sikap, pengetahuan, dan keterampilan yang dilakukan secara berimbang sehingga dapat digunakan untuk menentukan posisi relativ setiap siswa terhadap standar mata pelajaran fiqih

Secara lebih rinci disini penulis dapat menjelaskan tentang instrumen penilaian yang telah dilaksanakan pada masing-masing kompetensi pada mata pelajaran fiqih di MIN 1 Kota Bima:

a. Penilaian Kompetensi Sikap

Penilaian Sikap Dalam Praktek Wudhu (Fiqih Ibadah)

\begin{tabular}{|c|c|c|c|c|c|c|c|}
\hline \multirow{2}{*}{ No } & \multirow{2}{*}{ Nama } & \multicolumn{4}{|c|}{ Perilaku (Skor 1-6) } & \multirow{2}{*}{ Skor } & Nilai \\
\cline { 3 - 5 } & & $\begin{array}{c}\text { Bekerja } \\
\text { sama }\end{array}$ & Berinisiatif & $\begin{array}{c}\text { Penuh } \\
\text { Perhatian }\end{array}$ & $\begin{array}{c}\text { Bekerja } \\
\text { Sistematis }\end{array}$ & Perolehan & \\
\hline 1 & Ardin & 3 & 4 & 5 & 3 & 15 & 75 \\
\hline
\end{tabular}




\begin{tabular}{|l|l|l|l|l|l|l|l|}
\hline 2 & Awal & 4 & 4 & 5 & 5 & 18 & 90 \\
\hline 3 & Budi & 3 & 4 & 5 & 6 & 18 & 90 \\
\hline 4 & Chamim & 5 & 4 & 4 & 4 & 17 & 85 \\
\hline
\end{tabular}

Rumus :

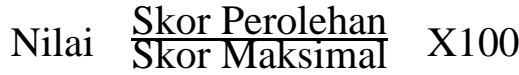

Dalam menilai kompetensi sikap sikap seperti yang dijelaskan diatas, penulis mengambil contoh penilaian terhadap empat siswa. Penilaian kompetnsi sikap ini sangat penting untuk diketahui oleh guru mata pelajaran fiqih di MIN 1 Kota Bima, supaya kedepan guru dapat meningkatkan kemampuan afektif yang dimiliki oleh siswa.

b. Penilaian Kompetensi Pengetahuan

Pada penilaian ini guru menilaia kompetensi pengetahuan yang dimiliki oleh siswa pada mata pelajaran fiqih di MIN 1 Kota Bima dengan menggunakan tes tertulis, tes lisan, dan penugasan. Istrumen tes tulis berupa soal pilihan ganda, isian, jawaban singkat, benar-salah, dan uraian. Berikut ini contoh instrument pnilaian kompetensi pengetahuan pembelajaran fiqih sebagai berikut:

A. Pilihlah jawaban yang paling tepat dengan mennyilang (X) huruf a,b,c atau d dari soal-soal sebagai berikut:

1. Ibadah yang telah diatur secara khusus oleh Allah SWT, dan sangat jelas dalil-dalilnya secara terperinci disebut ...
a. Ibadah Mahdhah
b. Ibadah Ghairu Mahdhah
c. Ibadah Sunan Muakad
d. Ibadah Sunan Ghairu Muakad

Satu soal diatas merupakan salah contoh instrumen tes tertulis berupa soal pilihan ganda yang dapat dilakukan oleh guru mata pelajaran fiqih untuk mengetahui kompetensi pengetahuan siswa. Dalam proses pelaksanaannya di MIN 1 Kota Bima telah berjalan dengan baik sesuai dengan target yang diharapkan.

c. Penilaian Kompetensi Keterampilan

Guru mata pelajaran fiqih di MIN 1 Kota Bima menilai kompetensi keterampilan melalui penilaian kerja, yaitu penilaian yang 
menuntut siswa mendemonstrasikan suatu kompetensi dengan menggunakan tes praktik, proyek, dan penilaian portofolio. Ibu Nurjanah menjelaskan bahwa tes praktek dinilai untuk melihat respon berupa keterampilan siswa dalam melakukan suatu aktifitas atau perilaku sesuai dengan tuntutan kompetensi. Sedangkan proyek adalah tugas-tugas belajar yang diberikan kepada siswa meliputi kegiatan perancangan, pelaksanaan, pelaporan secara tertulis maupun lisan dalam waktu tertentu. Selanjutnya Nurjanah menyebutkan, portofolio dilakukan dengan cara menilai menilai seluruh karya siswa yang bersifat reflektif-integratif untuk mengetahui minat, perkembangan dan prestasi siswa (Nurjanah, 2019).

Berikut contoh instrument penilaian kompetensi keterampilan dalam pembelajaran fiqih kelas VI di MIN 1 Kota Bima.

$\begin{array}{ll}\text { Nama Siswa } & \text { : Anita } \\ \text { Mata Pelajaran } & \text { : Fqih } \\ \text { Kelas/Semester } & \text { : VI/I } \\ \text { Tahun Pelajaran } & : \text { 2019-2020 } \\ \text { Satuan Pendidikan } & \text { MIN 1 Kota Bima } \\ \text { Tema Diskusi } & \text { : Mari Berwudhu }\end{array}$

\begin{tabular}{|c|c|c|c|}
\hline No & Aspek Yang Diamati & $\mathrm{Ya}$ & Tidak \\
\hline \multicolumn{4}{|c|}{ Rukun Wudhu } \\
\hline 1 & Niat & $\mathrm{V}$ & \\
\hline 2 & Membasuh Muka & $\mathrm{V}$ & \\
\hline 3 & Membasuh Dua Tangan Sampai Siku & $\mathrm{V}$ & \\
\hline 4 & Membasuh Kepala & $\mathrm{V}$ & \\
\hline 5 & Membasuh Kaki Hingga Mata Kaki & $\mathrm{V}$ & \\
\hline 6 & Tertib & $\mathrm{V}$ & \\
\hline \multicolumn{4}{|c|}{ Sunah-Sunah Wudhu } \\
\hline 1 & Membaca Basmallah & $\mathrm{V}$ & \\
\hline 2 & Berkumur-kumur & $\mathrm{V}$ & \\
\hline 3 & Membasuh Telapak Tangan Sampai Pergelangan & $\mathrm{V}$ & \\
\hline 5 & Memasukan Air Kedalam Hidung & & $\mathrm{V}$ \\
\hline 6 & Membasuh Kedua Telinga & & $\mathrm{V}$ \\
\hline 7 & Mendahulukan Kanan Atas Kiri & $\mathrm{V}$ & \\
\hline 8 & Tidak Berbicara Kecuali Terpaksa & $\mathrm{V}$ & \\
\hline 9 & Bersiwak & & $\mathrm{V}$ \\
\hline 10 & Membasuh Sebanyak Tiga kali & $\mathrm{V}$ & \\
\hline \multicolumn{2}{|r|}{ Skor Yang Dicapai } & \multicolumn{2}{|r|}{4} \\
\hline & Skor Maksimum & & 6 \\
\hline
\end{tabular}


Nilai $\frac{\text { Skor Perolehan }}{\text { Skor Maksimal X100 }}$

Nilai $\frac{12}{16} \quad X 100$

Nilai $=75$

Contoh intrumen penilaian diatas merupakan salah satu cara yang dilakukan oleh guru mata pelajaran fiqih dalam menilaian kompetensi keterampilan siswa di MIN 1 Kota Bima. Jika dilihat dari penerapannya, maka dapat disimpulkan bahwa siswa sudah dapat mengimpelemntasikan pengetahuannya tentang berwudhu melalui cara praktek. Meskipun contoh yang dijelaskan diatas hanya satu siswa, akan tetapi itu menggambarkan tentang bentuk keseriusan guru dalam melihat dan menilai kemampuan yang dimiliki oleh siswa.

\section{SIMPULAN}

Dalam perencanaannya proses pembelajaran Fiqih dengan pendekatan pembelajaran saintifik terdiri dari lima pengalaman belajar pokok: pertama, mangamati, kedua, menanya, ketiga, mengumpulkan informasi, keempat, mengasosiasi, dan kelima mengasosiasikan. Kelima tahapan pembelajaran tersebut didesain secara ssitematis dan terstruktur. Pembelajaran tematik dengan menggunakan pendekatan saintifik untuk mata pelajaran fiqih siswa kelas VI di MIN 1 Kota Bima adalah menggunakan pendekatan pembelajaran yang berpusat kepada siswa, menekankan pada proses pembelajaran yang berangkat dari dalam diri siswa sendiri. Maksudnya bahwa yang mengkonstruksi pengetahuan adalah siswa sendiri, bukan guru yang mentransfer pengetahuan kepada siswa. Guru disini hanya bertugas sebagai fasilitator dan dinamisator. Kegiatan pembelajarannya menuntut siswa aktif sehingga dapat menciptakan proses pembelajaran bermakna. Selain itu, Kegiatan penilaian untuk pembelajaran fiqih di MIN 1 Kota Bima pada pembelajaran tematik dengan pendekatan saintifk ini menekankan penggunaan penilaian autentik, yakni siswa dinilai pada aspek kompetensi pengetahuan, kompetensi sikap dan kompetensi keterampilan secara integrasi. 
DAFTAR PUSTAKA

Abdul Majid. 2013. Pembelajaran Tematik Terpadu, Bandung, PT Remaja Rosdakarya.

Andi Prastowo. 2015. Menyusun Rencana Pelaksanaan Pembelajaran (RPP) Tematik Terpadu: Implementasi Kurikulum 2013 Untuk SD/MI, Jakarta, Prenadamedia Group.

Andi Prastowo. 2013. Pengembangan Bahan Ajar Tematik Panduan Lengkap Aplikatif, Jogjakarta, DIVA Press.

Andewi Suhartini. 2012. Ushul Fiqih, Jakarta, Dirjen Pendidikan Islam Kemenag RI.

Creswell, J. W. 2014. Penelitian Kualitatif dan Desain Riset, Memilih Diantara Lima Pendekatan, Yogyakarta, Pustaka Pelajar.

Daryanto. 2014. Pendekatan Pembelajaran Saintifik Kurikulum 2013, Yogyakarta, Gava Media.

Fakrur Rozi. 2004. Pengajaran Ibadah, Yogyakarta, Pustaka Pelajar.

Gunawan. 2019. Wawancara Dengan Kepala Sekolah MIN 1 Kota Bima

Lukman Zain MS. 2009. Pembelajaran Fiqih, Jakarta, Dirjen Pendidikan Islam Depag RI.

Lukman Karim. 2019. Wawancara Dengan Wakasek Kurikulum MIN 1 Kota Bima

M. Hosnan. 2014. Pendekatan Saintfik dan Kontekstual Dalam Pembelajaran Abad 21: Kunci Sukses Implementasi Kurikulum 2013, Bogor, Ghalia Indonesia.

Mulyasa. 2013. Pengembangan dan Implementasi Kurikulum 2013, Bandung, PT Remaja Rosdakarya.

Nurjanah. 2019. Wawancara Dengan Guru Mata Pelajaran Fiqih Kelas V MIN 1 Kota Bima.

Permendikbud RI Nomor 81a Tahun 2013 Lampiran 4 Tentang Pedoman Umum Pembelajaran.

Rahmilah. 2019. Wawancara Dengan Guru Fiqih Kelas VI MIN 1 Kota Bima

Ridwan Abdullah Sani. 2013. Inovasi Pembelajara, Jakarta, Bumi Aksara.

Sri Andriani, Wawancara Dengan Guru Mata Pelajaran Fiqih Kelas VI MIN 1 Kota Bima.

Suharsimi Arikunto. 2006. Prosedur Penelitian Suatu Pendekatan Praktik, Jakarta, Rineka Cipta. 